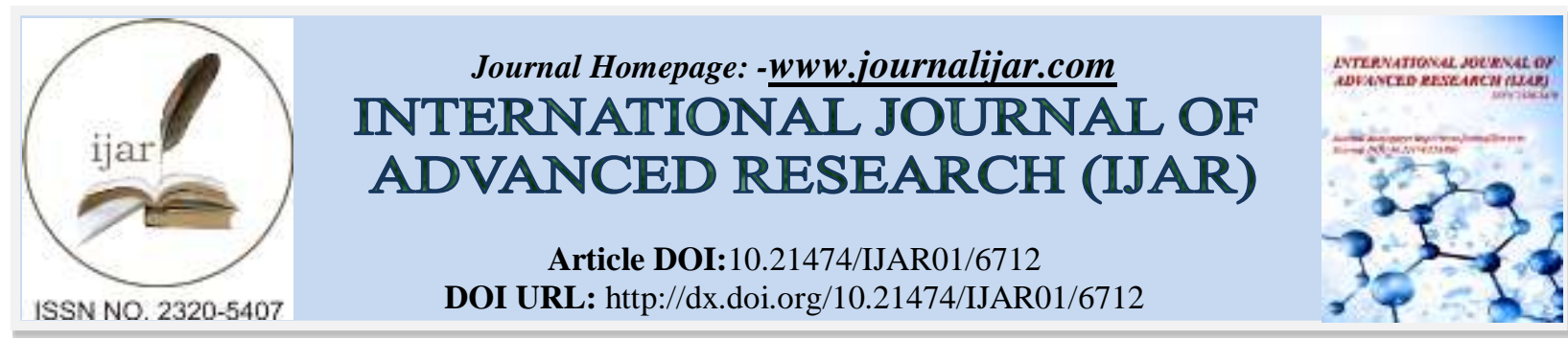

RESEARCH ARTICLE

\title{
MODELS OF ELECTRICAL POWER MANAGEMENT IN APPLICATION OF ENERGY CONSERVATION BASED ON THE ENVIRONMENT.
}

\section{Janter ${ }^{1}$, Herman Mawengkang ${ }^{2}$, Usman Ba'afai ${ }^{3}$ and Nasruddin M. $\mathbf{N}^{2}$.}

1. Study Program of Natural Resources Management and Environment, Postgraduate School, University of Sumatera Utara, Indonesia and Faculty of Engineering, University of Darma Agung, Indonesia.

2. Faculty of Mathematics and Natural Sciences, University of Sumatera Utara, Indonesia.

3. Faculty of Engineering, University of Sumatera Utara, Indonesia.

\section{Manuscript Info}

\section{Manuscript History}

Received: 10 January 2018

Final Accepted: 12 February 2018

Published: March 2018

Keywords:-

Electric power Energy conservation

Carbon emisson Light lamp efficacy.

\begin{abstract}
Utilization of conventional electrical energy as the fulfillment of living necessities for lighting and electrical equipment is increasing, which can cause problems in the provision of electrical energy. Energy management is needed to solve the problem of energy utilization, especially the problem of energy demand during peak load. The greatest energy consumption during peak loads is for building lighting at night, including street lighting. The use of electrical energy for the national public road lighting is getting bigger due to the increase in the length of national roads each year significantly. In North Sumatera Province, by the end of 2019 the total length of the national road segment is $2632.22 \mathrm{Km}$, an increase of $328.56 \mathrm{~km}$ from the previous road length. By increasing the power factor of the existing national street lighting and utilizing lamps with high efficacy and utilization of solar cells on the increase of national roads will be obtained energy conservation and the need for electrical power for the purposes of street lighting by increasing the road segment becomes fulfilled.
\end{abstract}

Copy Right, IJAR, 2018,. All rights reserved.

\section{Introduction:-}

Along with growing Needs of electrical energy that continues to increase, if it can not be met will cause the supply of electrical energy is disrupted.

Development of national roads is done to meet the needs of the community to drive. With the growth of national roads in North Sumatera, the need for electrical energy for street lighting is also increasing. Street lighting is used at night while at the same time there is a peak load on the power system. With the addition of this national road segment, a strategy is needed in the utilization of electric energy for street lighting. To meet the needs of electrical energy can be done with energy efficiency and energy saving done by adding equipment to improve the power factor[1]. Can also be done by decreasing active power losses and reactive power losses in power distribution systems [2].

Efficiency is one step in the implementation of energy conservation. Energy efficiency is an appropriate general term for using less energy to produce the same number of useful services or outputs. In the general public, sometimes energy efficiency is also defined as energy saving. Energy efficiency is an action of energy utilization that is smaller than energy that should be used at a level of equal energy production. Energy efficiency occurs on the consumer side associated with the use of electrical equipment. Through energy efficiency measures will be achieved significant energy conservation. Energy conservation can be achieved through systematic, planned, and integrated 
efforts to conserve energy resources and improve the efficiency of their utilization. Energy conservation is an efficient and rational use of energy without reducing the energy consumption that is really necessary. Energy efficiency will result in savings in energy consumption. Using sensor techniques to detect the number of vehicles and the required illumination level required to achieve energy savings[3]. Energy savings can also be obtained by applying solar cell technology with solar LED lamps automatic[4].

To obtain energy savings [5] is required review of 2 aspects as follows: 1. Technological aspect, 2. Economical aspect.

Energy conservation can also be obtained by replacing conventional street lamps with solar led street light with illumination lighting setting automatically[6].

In this research to anticipate the growth of electric power requirement due to the increase of national road segment to obtain energy conservation done by the way that is 1 . Increase power factor by addition of capacitor, 2 . Use light bulb with higher light efficacy, 3. Using solar cell off grid to serve LED to meet the energy for national arterial and collector roads, 4. Apply half lethal strategy from the number of lamps alternately taking into account the level of illumination still meets the minimum standards of lighting. The way that 4 is applied for the national collector road segment. From the 4 items above, can be determined the level of environmental pollution that occurs refers to the value of carbon emission factors for Indonesia established by the United Nations Development Project (UNDP) of $1.14 \mathrm{Kg} / \mathrm{KWh}$. To utilize solar cells as an energy source, solar irradiance is approximately $1000 \mathrm{~W} / \mathrm{m} 2$ at $0.5 \mathrm{~V}$ open circuit voltage[7]. By doing energy conservation if there is an increase of national road is no longer needed additional energy to serve lighting.

\section{Research Method:-}

\section{The Power Absorbed By The Lamp And Power Factor Correction:-}

Electrical power is calculated as follows:

$\mathrm{P}=$ V.I. $\operatorname{Cos} \varphi=\mathrm{S} . \operatorname{Cos} \varphi$

where: $\mathrm{P}$ is electric power

$\mathrm{V}$ is the utility voltage

I is the electric current

$\operatorname{Cos} \varphi$ is the power factor.

Energy is the power used in a single unit of time.

$\mathrm{W}=\mathrm{P} \times \mathrm{t}_{\mathrm{o}}$

where:

$\mathrm{W}$ is energy

$\mathrm{t}_{\mathrm{o}}$ is time

The energy absorbed by the lamp is

$\mathrm{W}=\mathrm{S} \times \mathrm{t}_{\mathrm{o}}$

$\mathrm{W}=(\mathrm{P} / \mathrm{pf}) \times \mathrm{t}_{\mathrm{o}}$

$\mathrm{W}=\mathrm{KWh} / \mathrm{pf}$

The reactive power required for power factor correction (Qc ) can be obtained as follows:

$\mathrm{Qc}=\mathrm{P}(\tan \varphi 1-\tan \varphi 2)$

The value of adding capacitor $(C)$ for power factor increase is

$\mathrm{Qc}=\mathrm{V}^{2} / \mathrm{Xc}$ or

$\mathrm{C}=\mathrm{Qc} / 2 \pi \mathrm{fV}^{2}$

By increasing the power factor by giving the capacitor will cause the value of power absorbed by the lamp

is smaller than it should be. So that energy conservation can be obtained

\section{Effect Of Light Efficacy On Illumination:-}

The efficacy of light is the ratio between the flux of light and the power consumption in lumen / watt units $\mathrm{K}=\varnothing / \mathrm{P}$ or $\emptyset=\mathrm{KxP}$

Where,

$\mathrm{K}$ is the efficacy of light $(\mathrm{Lm} / \mathrm{W})$

$\varnothing$ is the flux of light (Lm) 
$\mathrm{P}$ is the power consumption (Watt)

$\mathrm{I}$ is the intensity of light $(\mathrm{Cd})$

$\mathrm{I}=\varnothing / \omega=\mathrm{KxP} / 4 \pi$

If $\quad \mathrm{r}=\sqrt{h^{2}+c^{2}}$

Then, light illumination level at point $\mathrm{M}$ ( the point in the middle of the road )

Where,

$$
\mathrm{E}_{\mathrm{M}}=\mathrm{I} \times \operatorname{Cos} \psi / \mathrm{r}^{2}
$$

$\mathrm{E}_{\mathrm{M}}$ is Light illumination level in the middle of the road (Lux)

$\mathrm{r}$ is the distance of the lamp point at the road side to the point in the middle of the road $(\mathrm{m})$

$\mathrm{h}$ is the height of the lamppost $(\mathrm{m})$

$\mathrm{c}$ is the horizontal line, the distance from the projection point of the lamp end to the point in the middle of the road.

$\operatorname{Cos} \psi$ is the ratio of $h$ and $r$

With higher light efficacy will affect the smaller absorption power value to produce the same illumination rate.

\section{Capacity Of Solar Cells Module And Battery:- Capacity of solar cell module:-}

$\mathrm{W}_{\mathrm{SS}}=\mathrm{P}_{\mathrm{LED}} \times \mathrm{t}_{\mathrm{O}}$

Where,

$\mathrm{P}_{\mathrm{SS}}=($ Wss $\times \mathrm{Fm}) / \mathrm{DSE}$

$\mathrm{W}_{\mathrm{SS}}$ is Energy Generation (Wh)

$\mathrm{P}_{\mathrm{LED}}$ is power lights $(\mathrm{W})$

$\mathrm{t}_{\mathrm{o}} \quad$ is operating time

$\mathrm{P}_{\mathrm{SS}}$ is Capacity of solar cell module (W)

Fm is multiplier factors due to losses and efficiency

DSE is Duration of sun exposure

\section{Battery capacity:-}

Where,

$$
\begin{aligned}
& \mathrm{W}_{\text {Batt }}=\mathrm{P}_{\mathrm{LED}} \times \mathrm{t}_{\mathrm{c}} \\
& \mathrm{I}_{\text {Batt }}=\left(\mathrm{W}_{\text {Batt }} / \mathrm{V}_{\text {Batt }}\right) / \eta_{\text {Batt }}
\end{aligned}
$$

$\mathrm{W}_{\text {Batt }}$ is battery energy (Wh)

$\mathrm{I}_{\text {Batt }}$ is battery current (Ah)

$\mathrm{V}_{\text {Batt }}$ is battery voltage $(\mathrm{V})$

$\mathrm{t}_{\mathrm{c}} \quad$ is charging time $(\mathrm{S})$

$\eta_{\text {Batt }}$ is Efficiency of tubular battery and losses

\section{The Number Of Light Points:-}

The number of light points needed is

$\mathrm{T}=(\mathrm{L} / \mathrm{S})+1$

Where,

$\mathrm{T}$ is the number of light points

$\mathrm{L}$ is road length $(\mathrm{m})$

$\mathrm{S}$ is distance pole to pole $(\mathrm{m})$

\section{Result and Discussion:-}

\section{Result:-}

According to Indonesian National Standard, illumination for arterial road is 10-20 Lux and illumination for collector road is 3-7 Lux. As a reference for this study, the average illumination used for arterial roads is above 10 Lux and the average illumination for the collector road is above 5 Lux. The specifications of the bulb used are MBF, 400 Watt, 53 Lumen / watt for arterial road and MBF, 180 Watt, 53 Lumen / watt for collector road. The length of national road in North Sumatera Province is 2632,22 Km which consist of $1142 \mathrm{Kms}$ artery road and 1490,22 Kms collector road. 


\section{Power and illumination emitted:-}

Lamp type: MBF, 400 Watt, 53 lumens / watt

Road width: $8 \mathrm{~m}$ (arterial road)

$$
\begin{aligned}
\mathrm{h} & =11 \mathrm{~m} \\
\mathrm{c} & =2.95 \mathrm{~m} \\
\mathrm{r} & =\sqrt{11^{2}+2.95^{2}} \\
& =11.388 \mathrm{~m} \\
\operatorname{Cos} \psi & =11 / 11.388 \\
& =0.965 \\
\mathrm{I} & =53 \times 400 /(4 \times 3,14) \\
& =1687.898 \mathrm{~cd}
\end{aligned}
$$

Then,

$$
\begin{aligned}
\mathrm{E}_{\mathrm{M}} & =1687.898 \times 0,965 / 11.388^{2} \\
& =12.559 \operatorname{Lux}
\end{aligned}
$$

Lamp type: MBF, 180 Watt, 53 lumens / watt

Road width: 7 m (collector road)

$$
\begin{aligned}
\mathrm{h} & =8 \mathrm{~m} \\
\mathrm{c} & =2.6 \mathrm{~m} \\
\mathrm{r} & =\sqrt{8^{2}+2.6^{2}} \\
& =8.441 \mathrm{~m} \\
\cos \psi & =8 / 8.411 \\
& =0.951 \\
\mathrm{I} & =53 \times 180 /(4 \times 3,14) \\
& =759.554 \mathrm{~cd}
\end{aligned}
$$

Then,

$$
\begin{aligned}
\mathrm{E}_{\mathrm{M}} & =759.554 \mathrm{x} 0,951 / 8.411^{2} \\
& =10.210 \mathrm{Lux}
\end{aligned}
$$

Lamp type : LED, 100 Watt, 130 Lm/Watt.

Road width: $8 \mathrm{~m}$ ( arterial road)

$\mathrm{h}=8 \mathrm{~m}$

$\mathrm{c}=3.1 \mathrm{~m}$

$\mathrm{r}=\sqrt{8^{2}+3.1^{2}}$

$$
=8.57 \mathrm{~m}
$$

$$
\begin{aligned}
\operatorname{Cos} \psi & =8 / 8.57 \\
& =0.93
\end{aligned}
$$

$\mathrm{I}=100 \times 130 /(4 \times 3.14)$

$$
=1035.031 \mathrm{~cd}
$$

Then,

$$
\begin{aligned}
\mathrm{E}_{\mathrm{M}} & =1035.031 \times 0,93 / 8.57^{2} \\
& =13.106 \operatorname{Lux}
\end{aligned}
$$

Road width: 7 m (collector road)

$$
\begin{aligned}
\mathrm{h} & =8 \mathrm{~m} \\
\mathrm{c} & =2.6 \mathrm{~m} \\
\mathrm{r} & =\sqrt{8^{2}+2.6^{2}} \\
& =8.41 \mathrm{~m}
\end{aligned}
$$$$
\operatorname{Cos} \psi=8 / 8.41
$$$$
=0.95
$$

Then,

$$
\begin{aligned}
\mathrm{I} & =100 \times 130 /(4 \times 3.14) \\
& =1035.031 \mathrm{~cd}
\end{aligned}
$$

$\begin{aligned} \mathrm{E}_{\mathrm{M}} & =1035.031 \times 0,95 / 8.41^{2} \\ & =13.902 \mathrm{Lux}\end{aligned}$

$$
=13.902 \mathrm{Lux}
$$




\section{Improved MBF lamp power factor:-}

The use of mercury lamps as the national street lighting has limitations because the bulb has a power factor of 0.4 . In accordance with the standards stipulated by Directorate General of Highways, technical specifications section 8.7.2, determining the power factor of the installed lamps shall be at least 0.85 .

So, for each $\mathrm{P}=400$ Watt mercury lamp, pf: 0.4 , the requirement of apparent power $(\mathrm{S})$ is

$$
\mathrm{S}=400 / 0,4=1000 \mathrm{VA}
$$

With pf improvement: 0.85 , the requirement of apparent power $(\mathrm{S})$ is

$\mathrm{S}=400 / 0,85=470,588 \mathrm{VA}$

There is a decrease of S (VA) requirement of 529,412 VA for each mercury lamp, with the installation of capacitors of

$\mathrm{C}=400 \times 1.672 / 2 \pi \times 50 \times 220^{2}$

$=668.915 / 15,197,600$

$=440,145 \mu \mathrm{F}$

The required capacitor is $440,145 \mu \mathrm{F}, 250 \mathrm{VAC}$

\section{Capacity of solar module on each pole:-}

Sunlight can generate electrical energy at peak times of 1000 Watt $/ \mathrm{m}^{2}$. In solar cells with panel size Area $1 \mathrm{~m}{ }^{2}$, can produce power of $150 \mathrm{Wp}$. The solar cell that serves $\mathrm{P}_{\mathrm{LED}}$, $100 \mathrm{Watt}$ for 12 hours, at 18:00 to 6:00, with 1.2 as the multiplier factor due to losses and efficiency, and the average solar exposure time of 5.7 hours. Hence, the capacity of the solar cell module is

$\mathrm{P}_{\mathrm{SS}}=(100$ Watt $\mathrm{x} 12$ hours $\mathrm{x} 1.2) / 5.7$ hours

$$
=252 \mathrm{Wp}
$$

Then to serve the LED light load, 100 watts required 2 pieces of $150 \mathrm{Wp}$ solar cell panel.

For solar energy storage is used Battery with a voltage of 12 Volts, in charging time 12 hours. with the efficiency of tubular battery ( $\eta$ Batt) is $80 \%$, then

$$
\begin{gathered}
\text { Energy Battery }\left(\mathrm{W}_{\text {Batt }}\right)=\mathrm{P}_{\text {LED }} \times \text { Time } \\
=100 \times 12 \\
=1200 \mathrm{Wh}
\end{gathered}
$$

$$
\begin{aligned}
\text { Required battery current }\left(\mathrm{I}_{\text {Batt }}\right)=\left(\mathrm{W}_{\text {Batt }} /\right. & \left.\mathrm{V}_{\text {Batt }}\right) / \eta_{\text {Batt }} \\
& =(1200 / 12) / 0.8 \\
& =100 / 0.8 \\
& =125 \mathrm{Ah}
\end{aligned}
$$

Thus,

1 (one) set of solar cell modules requires battery with capacity, $\mathrm{I}_{\text {Batt }}=62.5 \mathrm{Ah}$.

\section{Discussion:-}

Energy conservation that can be obtained with the improvement of power factor:-

Power required by the arterial road

The number of light points needed is

$$
\begin{aligned}
\mathrm{T} & =(1,142,000 \mathrm{~m} / 40 \mathrm{~m})+1 \\
& =28,551 \text { pole }
\end{aligned}
$$

The power required by arterial road along the $1142 \mathrm{~km}$ with $40 \mathrm{~m}$ distance between the pole to the pole is

$$
\begin{aligned}
\mathrm{P} & =28,551 \times 400 \text { Watt } \\
& =11,420,400 \text { Watt }
\end{aligned}
$$

Energy absorbed by MBF lamp, 400 Watt, p.f 0.4 with operating time of 4145 hours in one year is

$$
\begin{aligned}
\mathrm{W} & =(11,420,400 / 0.4) \times 4145 \\
& =118,343,895,000 \mathrm{Wh} \\
& =118,343,895 \mathrm{KWh}
\end{aligned}
$$


Energy absorbed by MBF lamp, 400 Watt, p.f 0.85 with operating time of 4145 hours in one year is

$\mathrm{W}=(11,420,, 400 / 0.85) \times 4145$

$=55,689,294,117 \mathrm{Wh}$

$=55,689,294 \mathrm{KWh}$

Energy conservation $\left(\mathrm{W}_{\mathrm{c} 1}\right)$ that can be obtained within 1 year of operation time of 4145 hours is

$\mathrm{W}_{\mathrm{c} 1}=118,343,895 \mathrm{KWh}-55,689,294 \mathrm{KWh}$

$=62,654,601 \mathrm{KWh}$

b. Power required by the collector road

The number of light points needed is

$\mathrm{T}=(1,490,220 \mathrm{~m} / 40 \mathrm{~m})+1$

$=37,257$ pole

The power required by collector road along the $1490.22 \mathrm{~km}$ with $40 \mathrm{~m}$ distance between the pole to the pole is

$$
\begin{aligned}
\mathrm{P} & =37,257 \times 180 \text { Watt } \\
& =6,706,260 \text { Watt }
\end{aligned}
$$

Energy absorbed by MBF lamp, 180 Watt, p.f 0.4 with operating time of 4145 hours in one year is

$$
\begin{aligned}
\mathrm{W} & =(6,706,260 / 0.4) \times 4145 \\
& =69,493,619,250 \mathrm{Wh} \\
& =69,493,619 \mathrm{KWh}
\end{aligned}
$$

Energy absorbed by MBF lamp, 180 Watt, p.f 0.85 with operating time of 4145 hours in one year is

$$
\begin{aligned}
\mathrm{W} & =(6,706,260 / 0.85) \times 4145 \\
& =32,702,879,647 \mathrm{Wh} \\
& =32,702,879 \mathrm{KWh}
\end{aligned}
$$

Energy conservation $\left(\mathrm{W}_{\mathrm{c} 2}\right)$ that can be obtained within 1 year of operation time of 4145 hours is

$\mathrm{W}_{\mathrm{c} 2}=69,493,619 \mathrm{KWh}-32,702,879 \mathrm{KWh}$

$=36,790,740 \mathrm{KWh}$

Energy conservation that can be obtained with the improvement of power factor within 1 year of operation time of 4145 hours is

$$
\begin{aligned}
\mathrm{W}_{\mathrm{c}} & =\mathrm{W}_{\mathrm{c} 1}+\mathrm{W}_{\mathrm{c} 2} \\
& =62,654,601 \mathrm{KWh}+36,790,740 \mathrm{KWh} \\
& =99.445 \mathrm{GWh} .
\end{aligned}
$$

\section{Energy conservation that can be obtained with the higher light efficacy:-}

1. Power required by the arterial road

The number of light points needed is

$\mathrm{T}=(1,142,000 \mathrm{~m} / 40 \mathrm{~m})+1$

$=28,551$ pole

The power required by arterial road along the $1142 \mathrm{~km}$ with $40 \mathrm{~m}$ distance between the pole to the pole is

$\mathrm{P}=28,551 \times 100$ Watt

$=2,855,100$ Watt

Energy absorbed by LED, 100 Watt, p.f 0,95 with operating time of 4145 hours in one year is

$\mathrm{W}=(2,855,100 / 0.95) \times 4145$

$=12,457,252,105 \mathrm{Wh}$

$=12,457,252 \mathrm{KWh}$

By taking MBF, 400 watt, pf 0.4 as reference energy consumption, then energy conservation $\left(\mathrm{W}_{\mathrm{c} 1}\right)$ that can be obtained within 1 year of operation time of 4145 hours is

$$
\begin{aligned}
\mathrm{W}_{\mathrm{c} 1} & =118,343,895 \mathrm{KWh}-12,457,252 \mathrm{KWh} \\
& =105,886 \mathrm{GWh}
\end{aligned}
$$


2. Power required by the collector road

The number of light points needed is

$\mathrm{T}=(1,490,220 \mathrm{~m} / 40 \mathrm{~m})+1$

$=37,257$ pole

The power required by collector road along the $1490.22 \mathrm{~km}$ with $40 \mathrm{~m}$ distance between the pole to the pole is

$$
\begin{aligned}
\mathrm{P} & =37,257 \times 100 \mathrm{Watt} \\
& =3,725,700 \text { Watt }
\end{aligned}
$$

Energy absorbed by LED, 100 Watt, p.f 0.95 with operating time of 4145 hours in one year is

$$
\mathrm{W}=(3,725,700 / 0.95) \times 4145
$$

$=16,255,817,368 \mathrm{Wh}$

$=16,255,817 \mathrm{KWh}$

By taking MBF, 180 watt, pf 0.4 as reference energy consumption, then energy conservation $\left(\mathrm{W}_{\mathrm{c} 2}\right)$ that can be obtained within 1 year of operation time of 4145 hours is

$$
\begin{aligned}
\mathrm{W}_{\mathrm{c} 2} & =69,493,619 \mathrm{KWh}-16,255,817 \mathrm{KWh} \\
& =53.237 \mathrm{GWh}
\end{aligned}
$$

Energy conservation that can be obtained with the higher light efficacy within 1 year of operation time of 4145 hours is

$$
\begin{aligned}
\mathrm{W}_{\mathrm{c}} & =\mathrm{W}_{\mathrm{c} 1}+\mathrm{W}_{\mathrm{c} 2} \\
& =105,886 \mathrm{GWh}+53.237 \mathrm{GWh} \\
& =159.123 \mathrm{GWh} .
\end{aligned}
$$

\section{Energy conservation by applied half lethal strategy from the number of lamps:-}

From the calculations based on the illumination can be done strategy turn off half of the number of lights on the collector road.

The energy conservation obtained is half of energy absorbed by MBF lamps, 180 Watt, p.f 0.4 with operating time of 4145 hours in one year as follow,

$$
\begin{aligned}
\mathrm{W}_{\mathrm{c}} & =0.5 \times(6,706,260 / 0.4) \times 4145 \\
& =34,746,809,625 \mathrm{Wh} \\
& =34,746,809 \mathrm{KWh} \\
& =34.746 \mathrm{GWh}
\end{aligned}
$$

\section{Carbon Emission Reduction and carbon trading:-}

By using carbon emission factors established by the United Nations Development Project (UNDP) of $1.14 \mathrm{Kg} / \mathrm{KWh}$ and Carbon Price at a price of US \$ 1.83 per ton, then carbon emission reductions and carbon price can be obtained from energy conservation as follows:

1. Reduction of carbon emissions (CER) and Carbon Price (CP) by doing energy conservation obtained by power factor improvement is

$$
\begin{aligned}
\mathrm{CER} & =99.445 \mathrm{GWh} \times 1.14 \mathrm{Kg} \mathrm{CO}_{2} / \mathrm{KWh} \\
& =113.367 \mathrm{KTon} \mathrm{CO}_{2} \\
\mathrm{CP} & =113.367 \mathrm{KTon} \mathrm{CO}_{2} \times \text { US } \$ 1.83 \text { per Ton } \\
& =\mathrm{US} \$ 207,461.61
\end{aligned}
$$

2. Reduction of carbon emissions (CER) and Carbon Price (CP) by doing energy conservation obtained with the higher light efficacy is

$$
\begin{aligned}
\mathrm{CER} & =159.123 \mathrm{GWh} \times 1.14 \mathrm{Kg} \mathrm{CO}_{2} / \mathrm{KWh} \\
& =181.400 \mathrm{KTon}^{\mathrm{CO}_{2}} \\
\mathrm{CP} & =181.400 \mathrm{KT} \text {. } \mathrm{CO}_{2} \times \text { US } \$ 1.83 \text { per Ton } \\
& =\text { US } \$ 331,962
\end{aligned}
$$

3. Reduction of carbon emissions (CER) and Carbon Price (CP) by doing energy conservation obtained by applied half lethal strategy from the number of lamps is

$$
\begin{aligned}
\mathrm{CER} & =34 ., 746 \mathrm{GWh} \times 1.14 \mathrm{Kg} \mathrm{CO} / \mathrm{KWh} \\
& =39.610 \mathrm{KTon} \mathrm{CO}_{2}
\end{aligned}
$$




$$
\begin{aligned}
\mathrm{CP} & =39.610 \mathrm{KT} \text { Ton } \mathrm{CO}_{2} \mathrm{x} \text { US } \$ 1.83 \text { per Ton } \\
& =\mathrm{US} \$ 72,486.3
\end{aligned}
$$

\section{Analysis:-}

In this study there are 3 models as a strategy to get energy conservation that is

a.. By using capacitors to improve the power factor.

In this model, by improving the power factor the lamp power requirements are smaller than the specifications. Energy absorbed MBF with pf 0.4 for one year of $187,837,514 \mathrm{KWh}$ by raising pf 0.85 energy requirement to be $88,392,173 \mathrm{KWh}$.

b. Use of light bulbs with high light efficacy.

In this model, using MBF light bulbs with 53 Lumen / Watt efficacy, the energy requirement is $187,837,514 \mathrm{kwh}$ while using LED bulb with the efficacy of 130 Lumen / watt of energy requirement becomes smaller by $28,713,069$ KWh.

c. Applied half lethal strategy from the number of lamps

Based on the minimum of illumination can be done strategy turn off half of the number of lights, the energy requirement should be $187,837,514 \mathrm{KWh}$ to be slightly smaller by $153,090,704 \mathrm{KWh}$.

\section{Conclusion:-}

From the above study it can be concluded that the use of light bulbs with higher light efficacy provides the highest conservation of energy and reduces the greatest carbon emissions and provides the largest environmental conservation fund in the world carbon trade.

\section{Acknowledgements:-}

Our thanks to University of Sumatera Utara and University of Darma Agung for the support of the facilities provided.

\section{References:-}

1. S. Bhattacharyya et al.," Case Study On Power Factor Improvement," International Journal of Engineering Science and Technology (IJEST), Vol. 3 No.12 December 2011.

2. P.M. Moses, et al., "Reducing Real and Reactive Power Losses in the Power Distribution System by DFIG Placement and Sizing Using Ordinary PSO and HGAPSO :A Comparison," International Journal of Emerging Technology and Advanced Engineering, Vol. 2, Issue 11, Nov.2012.

3. B.E.Venkates, B.E.Depak, "Energy Saving by Implementation of Intelligent Systems in Lighting," International Journal of Engineering Research \& Technology (IJERT) Vol. 2 Issue 9, Sep. 2013.

4. M. Pandey, S. Pandey, "Intelligent Street Lighting System using Automatic Solar LED Lamps," International Journal of Science Technology \& Engineering (IJSTE), Vol. 2, Issue 4, Oct. 2015.

5. S. Escolar, et al., "Estimating Energy Savings in Smart Street Lighting by Using an Adaptive Control System,” International Journal of Distributed Sensor Networks, Vol. 2014, Article ID 971587.

6. A. S. Anees, et al., "Solar Powered LED Streetlight with Automatic Intensity Control," International Journal of Inovative Research in Electrical, Electronic, Instrumentation and Control Engineering, Vol. 3, Issue 6, June 2015.

7. E. L. Meyer, "Extraction of Saturation Current and Ideality Factor from Measuring Voc and Isc of Photovoltaic Modules," International Journal of Photoenergy, Vol. 2017, Article ID 8479487 